\title{
Pengaruh Sektor Pariwisata Terhadap Perekonomian dan Keruangan Kota Bukittinggi (Pendekatan Analisis Input Output)
}

\author{
Desi Arianti1 \\ Inspektorat Kota Bukittinggi \\ Artikel Masuk : 25 Agustus 2014 \\ Artikel Diterima : 30 September 2014
}

\begin{abstract}
Abstrak: Kota Bukittinggi adalah salah satu kota yang terletak di Propinsi Sumatera Barat. Walaupun tidak mempunyai potensi sumberdaya alam yang dapat dieksploitasi, kota Bukittinggi mempunyai potensi lain, yakni kondisi alam yang indah, udara yang sejuk, mempunyai tempat-tempat peninggalan bersejarah, serta terletak pada posisi yang strategis menjadikan kota ini berpotensi sebagai daerah kunjungan wisata. Karena potensi tersebut sektor pariwisata dijadikan sebagai salah satu sektor unggulan di Kota Bukittinggi, yang diharapkan dapat menjadi penggerak utama perekonomian kota. Penelitian ini dilakukan dengan pendekatan analisis input output, untuk mengkaji bagaimana pengaruh sektor pariwisata dan keterkaitannya dengan sektor lain terhadap perekonomian kota Bukittinggi. Selain itu secara spasial akan dilihat juga bagaimana pengaruh sektor pariwisata terhadap pola dan struktur ruang kota Bukittinggi. Pengaruh sektor pariwisata terhadap perekonomian kota Bukittinggi menunjukan peran sektor pariwisata terhadap total permintaan adalah 40,86\% apabila lapangan usaha di kelompokan menjadi sektor pertanian \& pertambangan, sektor industri, sektor pariwisata dan sektor jasa. Keterkaitan sektor pariwisata dengan sektor lain dilihat dari indeks daya penyebaran dan derajat kepekaan, semua sektor yang terkait dengan kegiatan kepariwisataan mempunyai indeks daya penyebaran $>1$. Tetapi indeks derajat kepekaan $>1$ hanya terjadi pada sektor perdagangan besar \& eceran dan pengangkutan, sedangkan sektor hotel, restoran dan hiburan \& rekreasi mempunyai indeks $<1$. Multiplier effect semua sektor yang terkait kegiatan pariwisata mempunyai pengaruh yang relatif besar terhadap dampak pengganda baik output, pendapatan rumah tangga dan tenaga kerja. Penerapan skenario input finansial, memperlihatkan pengaruh sektor pariwisata terhadap perekonomian Kota Bukittinggi akan lebih besar apabila input finansial dialokasikan lebih besar terhadap sektor-sektor pariwisata, baik dalam bentuk pengeluaran belanja pemerintah maupun investasi. Keberadaan objek wisata di sekitar pusat kota telah mempengaruhi struktur kota, dimana kegiatan dan usaha yang terkait dengan pariwisata tertarik untuk berlokasi mendekati objek wisata. Namun pola perkembangan kota ke arah timur, utara dan selatan kota lebih dipengaruhi oleh keberadaan jaringan jalan.
\end{abstract}

Kata Kunci: Sektor Pariwisata, Analisis Input Output, Pola dan Struktur Ruang

Bukittinggi city is one of the city located in the province of West Sumatra . Although it does not have the potential of natural resources that can be exploited, Bukittinggi has another potential, which is a beautiful natural conditions, the air is cool, has a historic heritage places, and is located in a strategic position potentially make this city as tourists visiting the area.

\footnotetext{
${ }^{1}$ Korespondensi Penulis: Inspektorat Kota Bukittinggi, Sumatera Barat, Indonesia email: c_hichie@yahoo.co.id
} 


\section{Pengaruh Sektor Pariwisata Terhadap Perekonomian dan Keruangan Kota Bukittinggi}

Because of the potential of the tourism sector serve as a leading sector in the city of Bukittinggi, which is expected to be the main driver of the city economy. This research was conducted with input-output analysis approach, to examine how the influence of the tourism sector and linkages with other sectors of the economy of the town of Bukittinggi. Moreover it will be seen also how the spatial effect of the tourism sector on the pattern and structure of urban space Bukittinggi. The influence of the tourism sector to the economy of Bukittinggi shows the role of the tourism sector to the total demand is $40.86 \%$ when grouped into the business field of agriculture and mining sector, industrial sector, tourism sector and the service sector. Linkages with other sectors of the tourism sector seen from the spread of the power index and the degree of sensitivity, all sectors related to tourism activities have spread of power index $>1$. But the degree of sensitivity index $>1$ only occurs in large \& retail trade sector and the transport, while the hotel secto, restaurants and entertainment and recreation has index $<1$. Multiplier effect of all relevant sectors of tourism activities have a relatively large effect on both the output multiplier effects, household income and employment. Application of financial input scenarios, showing the influence of the tourism sector on the economy will be larger Bukittinggi if allocated greater financial inputs to the sectors of tourism, both in the form of government spending and investment spending. The existence of attractions around the city center has affected the structure of the city, where the activity and tourism-related businesses keen to be located closer to attractions. However, the pattern of urban development to the east, north and south of the city is more influenced by the presence of the road network.

Keywords: Tourism Sector, Input Output Analysis, Pattern and Structure Space

\section{Pendahuluan}

Salah satu tujuan pembangunan suatu daerah adalah meningkatkan perekonomian daerah tersebut. Peningkatan perekonomian tidak hanya berorientasi pada perkembangan dan pertumbuhan Pendapatan Domestik Regional Bruto (PDRB) saja, tetapi itu juga mempertimbangkan laju pertumbuhan dan pertambahan penduduk. Boediono dalam Tarigan (2004 : 44), mengatakan bahwa pertumbuhan ekonomi adalah proses kenaikan output perkapita dalam jangka panjang, di mana persentase pertambahan output haruslah lebih tinggi dari dari persentase pertambahan jumlah penduduk, dan ada kecenderungan pertumbuhan ini akan berlanjut dalam jangka panjang.

Sejak diberlakukannya UU No. 32 Tahun 2004 tentang Otonomi Daerah, setiap daerah diberikan kebebasan dan kewenangan untuk menentukan arah pembangunan ekonominya masing-masing. Untuk itu diperlukan kemampuan daerah dalam menggali dan mengembangkan potensi-potensi yang dimiliki sebagai sumber kegiatan perekonomian. Penentuan sektor basis dan unggulan diharapkan dapat berperan sebagai penggerak utama (prime mover) dalam pertumbuhan suatu wilayah. Karena setiap perubahan yang terjadi pada sektor basis akan menimbulkan efek ganda (multiplier effect) dalam perekonomian regional (Adisasmita, 2005 : 28). Selain itu sektor basis/strategis diharapkan dapat mendorong dan menarik sektor-sektor lain untuk terintegrasi secara bersama-sama dalam meningkatkan perekonomian suatu daerah.

Kota Bukittinggi adalah salah satu kota yang berada di Provinsi Sumatera Barat. Kota ini tidak mempunyai potensi sumber daya alam berupa hutan, mineral, gas bumi dan perikanan laut yang dapat dieksploitasi sebagai sumber perekonomian kota. Namun Kota Bukittinggi terletak pada posisi yang strategis, yakni berada pada posisi silang lintas ekonomi Barat-Timur dan Utara-Selatan wilayah regional Sumatera. Selain itu alam yang indah dan topografi wilayah yang pada umumnya bergelombang dan berbukit menjadikan udaranya sejuk dan menyegarkan, disamping memiliki beberapa objek wisata, 
menyebabkan Kota Bukittinggi menjadi daerah tujuan wisata dan tempat peristirahatan yang terkenal di Provinsi Sumatera Barat. (RKPD Kota Bukittinggi Tahun 2012). Dijadikannya sektor pariwisata sebagai salah satu sektor unggulan di Kota Bukittinggi, tentu akan berpengaruh terhadap pembangunan daerah, baik secara ekonomi maupun keruangan.

Di lihat dari perannya terhadap PDRB Tahun 2012 sumbangan sektor pariwisata (sektor perdagangan besar \& eceran, hotel, restoran, pangangkutan, dan hiburan \& rekreasi) adalah sebesar 36,93\%. Angka ini menunjukan sumbangan yang tinggi dan mendominasi terhadap PDRB. Tetapi apabila di lihat secara sektoral, selain sektor perdagangan besar \& eceran dan sektor pengangkutan sumbangan sektor lain seperti hotel, restoran dan hiburan \& rekreasi relatif kecil yaitu dibawah 3\%. Hanya saja besar dan kecilnya persentase sumbangan suatu sektor terhadap PDRB bukan merupakan satusatunya acuan bahwa sektor tersebut dapat dikembangkan atau tidak sebagai sektor unggulan dan strategis. Perlu dilakukan kajian yang mendalam untuk mendapatkan data dan informasi yang berguna bagi penentuan perencanaan pembangunan dimasa depan (Arsyad, 1999 : 109), dan apakah sektor tersebut dapat memberikan efek pengganda baik terhadap output, pendapatan rumah tangga dan tenaga kerja, serta dapat menjadi sektor penarik dan pendorong sektor lain untuk dapat tumbuh dan berkembang. Sejauh ini belum diketahui seberapa besar pengaruh sektor pariwisata terhadap perekonomian Kota Bukittinggi secara komprehensif. Untuk itu perlu dikaji "Bagaimana pengaruh sektor pariwisata dan keterkaitannya dengan sektor lain terhadap perekonomian dan keruangan Kota Bukittinggi”.

\section{Metode Penelitian}

Penelitian ini menggunakan pendekatan positivistik. Dimana filsafat positivistik memandang realitas/gejala/fenomena dapat diklasifikasikan, relatif tetap, konkrit, teramati, terukur dan hubungan gejala bersifat sebab akibat Sugiyono : 2012). Metode penelitian yang digunakan adalah metode kuantitatif. Menurut Nazir (2003), metode penelitian merupakan satu kesatuan sistim yang terdiri dari prosedur dan teknik yang perlu dilakukan dalam suatu penelitian. Proses penelitian kuantitatif bersifat linear, dimana langkah-langkahnya dimulai dari rumusan permasalahan, kemudian untuk menjawab sementara rumusan permasalahan digunakan konsep dan teori, selanjutnya mengumpulkan data dan melakukan analisis data dengan teknik statistik tertentu untuk menjawab rumusan masalah dan terakhir membuat kesimpulan dan saran (Sugiyono : 2012). Dalam penelitian ini langkah-langkah yang dilakukan setelah menetapkan rumusan masalah dan merumuskan beberapa konsep dan teori adalah mengumpulkan data yang diperlukan yaitu berupa data sekunder dan mengolah data yang ada melalui alat analisis pendekatan Input Output dengan bantuan alat microsoft office excel 2007.

Untuk mencapai sasaran dan tujuan dari penelitian ini tahapan analisis yang akan dilakukan adalah :

a. Penyusunan Tabel Input Output Kota Bukittinggi berdasarkan Tabel Input Output dasar Sumatera Barat hasil updating tahun 2012, dengan metode LQ.

Langka-langka penyusunannya yaitu :

- Pengelompokan (agregası) Tabel IO Sumatera Barat Tahun 2007 dari 75 sektor menjadi 16 sektor.

- Mengupdate menjadi Tabel Input Output Tahun 2012 dengan metode RAS. Nazara (2005 : 145). Rumus umum metode RAS adalah:

$$
\mathrm{A}^{1}=\mathrm{R}^{1} \mathrm{~A}(\mathrm{o}) \mathrm{S}
$$


- Mempersiapkan nilai LQ Kota Bukittinggi Tahun 2012. Perhitungan LQ sebagai berikut:

$$
L Q_{i}=\frac{Y_{i}^{R} / Y_{t}^{R}}{Y_{i}^{N} / Y_{t}^{N}}
$$

Dimana :

$\mathrm{LQ}_{\mathrm{i}} \quad$ : nilai LQ sektor i

$\mathrm{Y}_{\mathrm{i}}^{\mathrm{R}} \quad$ : nilai sektor I pada wilayah regional

$\mathrm{Y}_{\mathrm{t}}{ }^{\mathrm{R}} \quad$ : nilai total sektor pada wilayah regional

$\mathrm{Y}_{\mathrm{i}} \mathrm{N} \quad$ : nilai sektor I pada wilayah nasional

$\mathrm{Y}_{\mathrm{t}^{\mathrm{N}}} \quad$ : nilai total sektor pada wilayah nasional

- Estimasi koefisien input (matriks teknologi) Kota Bukittinggi dengan metode Location Qoutient (LQ). Nilai LQ $\geq 1$, maka nilai koefisien Sumatera Barat dapat langsung diserap sebagai nilai koefisien Kota Bukittinggi sedangkan LQ $<1$, maka nilai LQ harus dikalikan dengan angka koefisien Sumatera Barat.

b. Mengidentifikasi peranan sektor-sektor dalam struktur perekonomian melalui :

- Menyusun matrik kooefisien input atau kooefisien teknologi [A]

$$
a_{i j}=\frac{z i j}{x_{j}}
$$

- Menghitung matrik identitas [I]

- Menghitung matrik leontif [I - A] dan invers matrik leontif [I - A] -1

c. Menganalisis keterkaitan antar sektor dalam perekonomian

Keterkaitan kedepan dapat dihitung dengan rumus :

- Langsung $: \operatorname{FLi}(\mathrm{d})=\sum_{j=1}^{n}$ ai $\boldsymbol{j}$

- Total $\quad:$ FLi $(\mathrm{d}+\mathrm{i})=\sum_{j=1}^{n} g i j$

Keterkaitan kebelakang dengan rumus :

- Langsung $: \operatorname{BLj}(\mathrm{d})=\sum_{i=1}^{n}$ aij

- Total :BLj $(\mathrm{d}+\mathrm{i})=\sum_{i=1}^{n} g i j$

Dimana :

FLi (d) = keterkaitan kedepan sektor i langsung

$\mathrm{FLi}(\mathrm{d}+\mathrm{i}) \quad=$ keterkaitan kedepan sektor i total

$\operatorname{BLj}(\mathrm{d}) \quad=$ keterkaitan kebelakang sektor i langsung

$\operatorname{BLj}(\mathrm{d}+\mathrm{i}) \quad=$ keterkaitan kebelakang sektor $\mathrm{i}$ total

aij $\quad=$ koefisien input sektor $\mathrm{i}$ ke sektor $\mathrm{j}$

gij $\quad=$ elemen pada matrik invers leontif $=[\mathrm{I}-\mathrm{A}]^{-1}$

Indeks Daya Penyebaran ( $\alpha \mathrm{j})$ dan Derajat Kepekaan ( $\beta \mathrm{i})$ dengan rumus :

$$
\mathbf{a j}=\frac{\sum_{i=1}^{n} g i j}{i / n \sum_{i} \Sigma_{j} g i j}
$$

$$
\beta \mathbf{i}=\frac{\sum_{j=1}^{n} g i j}{i / n \sum_{i} \Sigma_{j} g i j}
$$

Dimana :

$\alpha \mathrm{j} \quad=$ indekss daya penyebaran

$\beta \mathrm{i} \quad=$ indeks derajat kepekaan

gij = elemen pada matrik invers leontif $=[\mathrm{I}-\mathrm{A}]^{-1}$

$\alpha \mathrm{j}>1$ dan $\beta \mathrm{i}>1$ merupakan sektor yang strategis dalam memacu pertumbuhan ekonomi

d. Menganalisis dampak pengganda 
Pengganda output dengan rumus :

$$
\mathrm{Oj}=\sum_{i=1}^{n} g i j
$$

Pengganda pendapatan rumah tangga dengan rumus :

$$
\mathrm{Yj}=\sum_{i=1}^{n} P \boldsymbol{i} \cdot g i \boldsymbol{j}
$$

Pengganda lapangan kerja dengan rumus :

$$
\mathrm{Ej}=\sum_{i=1}^{n} w i \cdot g i j
$$

\section{Dimana :}

$\mathrm{Oj} \quad=$ angka pengganda output sektor $\mathrm{j}$

$\mathrm{Yj} \quad=$ angka pendapatan rumah tangga

$\mathrm{Pi} \quad=$ koefisien input upah/gaji

$\mathrm{Ej} \quad=$ angka pengganda lapangan kerja

wi = rata-rata output setiap pekerja $(\mathrm{Xj} / \mathrm{Lj})$

$\mathrm{Xj} \quad=$ total output sektor $\mathrm{j}$

$\mathrm{Lj} \quad=$ tenaga kerja sektor $\mathrm{j}$

Gij = elemen pada matrik invers leontif $=[\mathrm{I}-\mathrm{A}]^{-1}$

e. Menganalisis skenario. Analisis skenario dengan menstimulasikan perubahan pada permintaan akhir belanja pemerintah dan investasi (Pembentukan Modal Tetap Bruto). Angka perubahan ini dilihat dan dihitung dengan mengaplikasikannya terhadap angka pengganda, output, pendapatan maupun tenaga kerja. Sehingga akan diketahui input finasial dari permintaan akhir yang optimal.

f. Menganalisis Pengaruh Sektor Pariwisata Terhadap Pola dan Struktur Ruang Kota Bukittinggi. Analisis ini dilakukan dengan mengidentifikasi persebaran kegiatan pariwisata yang ada di Kota Bukittinggi, dan pengaruhnya terhadap perkembangan pola dan struktur ruang Kota Bukittinggi.

\section{Gambaran Umum Lokasi}

Kota Bukittinggi adalah salah satu kota yang terletak di bagian tengah Provinsi Sumatera Barat, dengan luas wilayah $25,239 \mathrm{~km}^{2}$. Secara Geografis Kota Bukittinggi terletak pada di tengah-tengah Kabupaten Agam. Sehingga secara administratif Kota Bukittinggi seluruhnya berbatasan dengan wilayah Kabupaten Agam. Wilayah administratif Kota Bukittinggi terdiri atas 3 kecamatan dan 24 kelurahan. Tiga kecamatan tersebut yaitu Kecamatan Guguk Panjang, Kecamatan Mandiangin Koto Selayan dan Kecamatan Aur Birugo Tigo Baleh. 


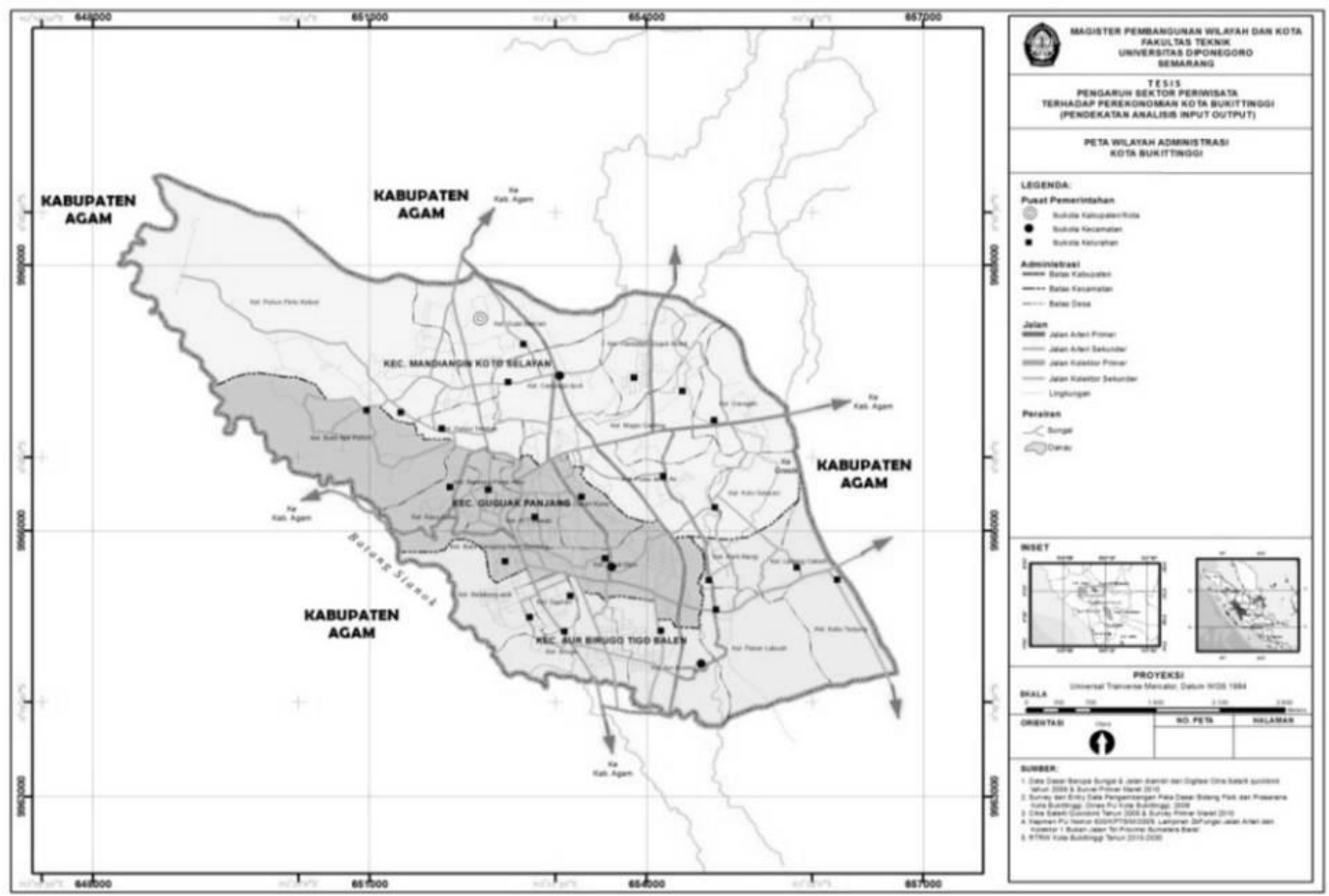

Gambar 1. Peta Administrasi Kota Bukittinggi

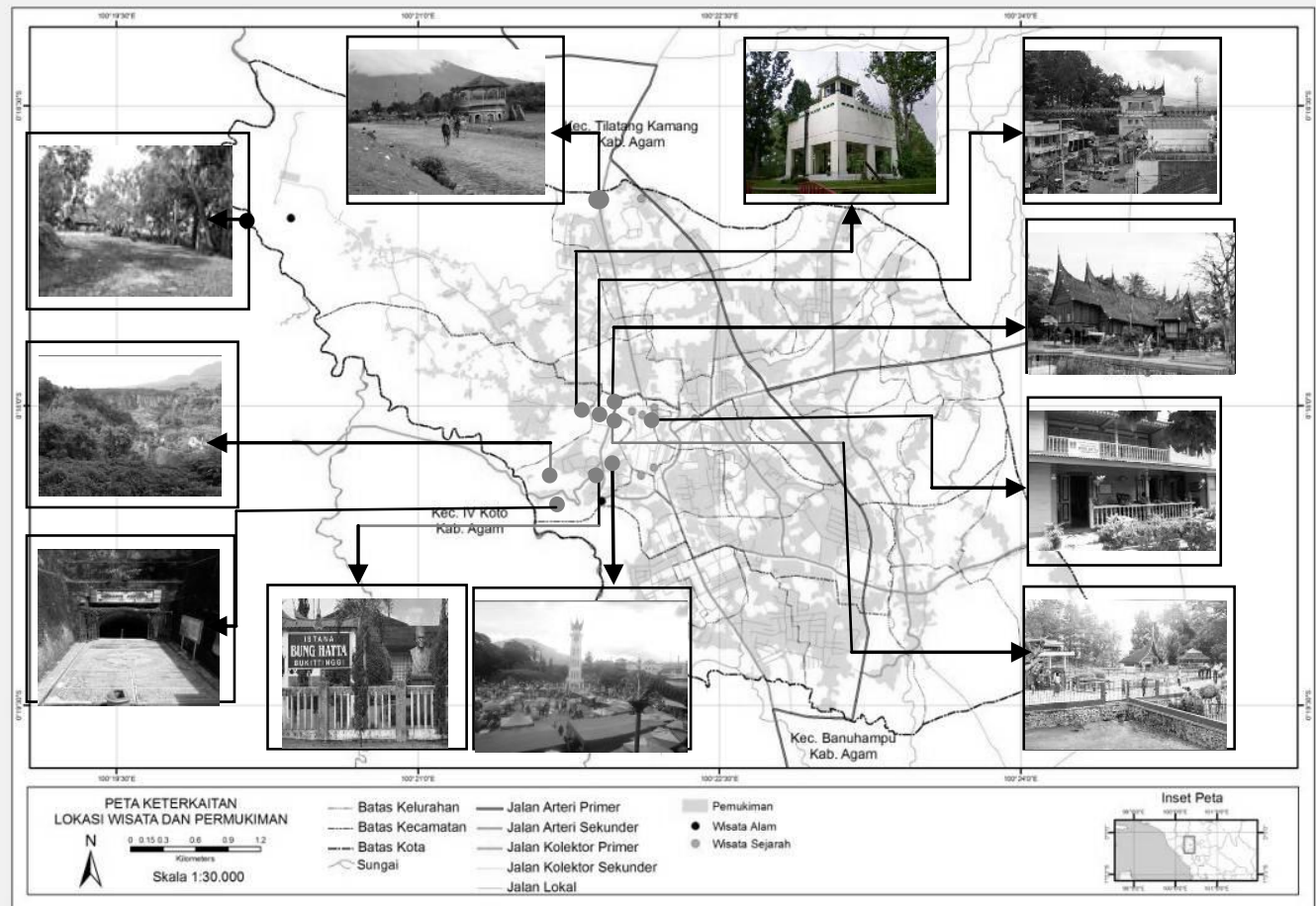

Sumber: RTRW Kota Bukittinggi 2010-2030, Google \& pengamatan, 2013

\section{Gambar 2. Sebaran Objek Wisata}


Jumlah kunjungan wisatawan baik mancanegara maupun nusantara ke Kota Bukittinggi pada Tahun 2003 sebanyak 180.260, dan meningkat pada tahun 2012 mencapai 386.995 (Disbudpar Kota Bukittinggi: 2013). Angka ini menunjukaan adanya perkembangan dan peningkatan. Selain peningkatan jumlah kinjungan wisatawan, gambaran potensi pariwisata lainnya di Kota Bukittinggi dapat diketahui dari potensi objek wisata serta berbagai fasilitas pendukungnya. Jenis objek wisata yang ada di Kota Bukittinggi berupa wisata alam dan wisata sejarah dan budaya. Gambar 2 menunjukan sebaran objek wisata yang ada di Kota Bukittinggi. Fasilitas pendukung kegiatan pariwisata yang tercatat pada Dinas Kebudayaan dan Pariwisata Kota Bukittinggi tahun 2012 seperti hotel berjumlah sebanyak 70 unit, restoran, rumah makan dan cafe sebanyak 38 unit, biro perjalanan wisata sebanyak 25 unit, toko souvenir/kerajinan sebanyak 7 unit, dan usaha sulaman/bordir sebanyak 6 unit.

\section{Kajian Pengaruh Sektor Pariwisata Terhadap Perekonomian dan Keruangan Kota Bukittinggi}

Pariwisata pada dasarnya adalah melakukan perjalanan untuk tujuan dan maksud tertentu dalam memenuhi kebutuhan, baik psikologis maupun fisik. Pendit (1999) mengatakan bahwa pariwisata adalah kepergian orang-orang sementara dalam jangka waktu pendek ke tempat-tempat tujuan di luar tempat tinggal dan bekerja sehari harinya serta kegiatan-kegiatan mereka selama berada di tempat-tempat tujuan tersebut, ini mencakup kepergian untuk berbagai maksud, termasuk kunjungan seharian atau darmawisata/ ekskursi. Aktivitas dilakukan selama mereka tinggal di tempat yang dituju dan fasilitas dibuat untuk memenuhi kebutuhan mereka (Marpaung : 2002).

Keseluruhan kegiatan usaha yang dilakukan sehingga dapat dinikmati wisatawan mulai awal ketertarikan untuk berwisata, menikmati lokasi DTW sampai pada proses akhir wisatawan tersebut pulang merupakan industri pariwisata. Industri pariwisata mempunyai sifat yang khas, tidak hanya melibatkan banyak industri, seperti transportasi, akomodasi, jasa boga, atraksi, retail, juga bersifat menyerap banyak tenaga kerja (Wardiyanta : 2006). Spillane (1994) mengkategorikan lima bidang dalam industri pariwisata antara lain : hotel dan restoran, tour \& travel, transportasi, pusat wisata dan souvenir, serta bidang pendidikan kepariwisataan. Sedangkan Damardjati dalam Karyono (1997) menggolongkan usaha-usaha pariwisata dalam 4 golongan besar yaitu: (1) Transportasi (2) Akomodasi dan perusahaan pangan (3) Perusahaan Jasa Khusus (4) Penyediaan barang.

Petters dan Bryden dalam (Soekadijo: 1997), merumuskan 5 hal dampak positif pengembangan pariwisata yang di jadikan tujuan pengembangan pariwisata sebagai berikut: (1) Menyumbang kepada neraca pembayaran, (2) Menyebarkan pembangunan ke daerah-daerah yang non industri, (3) Menciptakan kesempatan kerja, (4) Dampak pada pembangunan ekonomi pada umumnya melalui dampak pengganda (multiflier effect), dan (5) Keterkaitan Sektor Pariwisata dengan Sektor Lain dalam Perekonomian

Perencanaan pembangunan identik dengan ekonomi pembangunan, karena strategi ekonomi pembangunan dapat diterjemahkan dengan perencanaan pembangunan melalui program dan kegiatan yang terkoordinir dari perencanaaan pembangunan (Daryanto dan Yundi: 2010). Baik dalam perencanaan nasional maupun perencanaan pembangunan daerah, terdapat beberapa pendekatan perencanaan yang dapat dilakukan, diantaranya pendekatan sektoral dan pendekatan regional/wilayah. Pendekatan sektoral adalah dimana seluruh kegiatan ekonomi di dalam wilayah perencanaan dikelompokan atas sektor-sektor, selanjutnya setiap sektor di analisis satu per satu. Salah satu pendekatan sektoral yang sekaligus melihat kaitan pertumbuhan antara satu sektor dengan sektor lainnya dan sebaliknya dikenal dengan nama analisis masukan-keluaran (input-output analysis). Pendekatan regional melihat pemanfaatan ruang serta interaksi berbagai kegiatan 
dalam ruang wilayah. Sehingga terlihat perbedaan fungsi ruang yang satu dengan ruang yang lain dan bagaimana ruang itu berinteraksi untuk diarahkan kepada tercapainya kehidupan yang efisien dan nyaman (Tarigan : 2005). Perencanaan ruang wilayah adalah perencanaan penggunaan/pemanfaatan ruang wilayah, yang intinya adalah perencanaan penggunaan lahan (land use planning) dan perencanaan pergerakan pada ruang tersebut.

\section{Analisis Pengaruh Sektor Pariwisata dan Keterkaitannya dengan Sektor Lain Terhadap Perekonomian dan Keruangan Kota Bukittinggi}

\section{Identifikasi Peranan Sektor Pariwisata dalam Struktur Perekonomian}

Berdasarkan Tabel Input Output Tahun 2012 total permintaan pada perekonomian Kota Bukittinggi adalah sebesar Rp. 4.487.365,50 juta, dengan komposisi 69,62\% untuk permintaan akhir dan 30,38\% untuk permintaan antara. Peran sektor pariwisata (sektor perdagangan besar \& eceran, hotel, restoran, pengangkutan dan hiburan \& rekreasi) terhadap perekonomian adalah sebesar 40,86\% apabila sektor lapangan usaha dikelompokan dalam sektor pertanian \& pertambangan, sektor industri, sektor pariwisata dan sektor jasa. Permintaan terhadap sektor yang berkaitan dengan kegiatan kepariwisataan terlihat bahwa lebih dari 55\% merupakan permintaan untuk memenuhi permintaan akhir. Permintaan antara yang bertujuan untuk digunakan sebagai input oleh sektor lain dalam proses produksi relatif kecil terutama sektor hotel dan restoran yaitu hanya sebesar $1,80 \%$ dan $4,73 \%$.

\section{Analisis Keterkaitan (Linkage) Sektor Pariwisata dengan Sektor lain}

Keterkaitan kebelakang sektor pariwisata dengan sektor-sektor lainnya dalam perekonomian Kota Bukittinggi sesuai Tabel 1 menjelaskan bahwa semua sektor yang berhubungan dengan kegiatan pariwisata mempunyai nilai keterkaitan kebelakang yang tinggi dengan ranking $2-6$ dari 16 sektor lapangan usaha dalam perekonomian. Ini memperlihatkan bahwa sektor pariwisata merupakan salah satu sektor yang strategis dan dapat memacu pertumbuhan ekonomi di Kota Bukittinggi, karena sektor pariwisata di dalam menghasilkan outputnya membutuhkan input dari sektor lain.

Sedangkan untuk keterkaitan kedepan sektor pariwisata dengan sektor-sektor lain dalam perekonomian Kota Bukittinggi, terlihat bahwa hanya sektor perdagangan besar \& eceran dan pengangkutan yang mempunyai nilai yang tinggi yaitu ranking 1 dan 3 . Sedangkan sektor lainnya seperti sektor hotel, restoran dan hiburan \& rekreasi hanya berturut-turut ranking 13, 14 dan 8 dari 16 sektor lapangan usaha yang ada.

Tabel 1. Nilai Keterkaitan dan Indeks Daya Penyebaran Derajat Kepekaan

\begin{tabular}{|c|c|c|c|c|c|c|c|}
\hline \multirow{2}{*}{ No } & \multirow{2}{*}{ Sektor } & \multicolumn{2}{|c|}{$\begin{array}{l}\text { Keterkaitan } \\
\text { Kebelakang }\end{array}$} & \multicolumn{2}{|c|}{$\begin{array}{c}\text { Keterkaitan } \\
\text { kedepan }\end{array}$} & \multirow{2}{*}{$\begin{array}{c}\text { Indeks } \\
\text { Daya } \\
\text { Penye- } \\
\text { baran }\end{array}$} & \multirow{2}{*}{$\begin{array}{c}\text { Indeks } \\
\text { Derajat } \\
\text { Kepe- } \\
\text { kaan }\end{array}$} \\
\hline & & Nilai & $\begin{array}{l}\text { Ran- } \\
\text { king }\end{array}$ & Nilai & $\begin{array}{l}\text { Ran- } \\
\text { king }\end{array}$ & & \\
\hline 1 & Tanaman bahan makanan & 1,111 & 15 & 1,041 & 10 & 0,772 & 0,723 \\
\hline 2 & Tanaman perkebunan & 1,406 & 10 & 1,002 & 15 & 0,977 & 0,696 \\
\hline 3 & Peternakan dan hasilnya & 1,283 & 13 & 1,104 & 7 & 0,891 & 0,767 \\
\hline 4 & Perikanan & 1,088 & 16 & 1,024 & 11 & 0,756 & 0,711 \\
\hline 5 & Pertambangan dan penggalian & 1,372 & 12 & 1,000 & 16 & 0,953 & 0,695 \\
\hline 6 & Industri pengolahan & 1,382 & 11 & 2,085 & 4 & 0,960 & 1,448 \\
\hline 7 & Listrik, gas dan air bersih & 1,907 & 1 & 1,094 & 8 & 1,324 & 0,760 \\
\hline
\end{tabular}




\begin{tabular}{|c|c|c|c|c|c|c|c|}
\hline \multirow{2}{*}{ No } & \multirow{2}{*}{ Sektor } & \multicolumn{2}{|c|}{$\begin{array}{l}\text { Keterkaitan } \\
\text { Kebelakang }\end{array}$} & \multicolumn{2}{|c|}{$\begin{array}{l}\text { Keterkaitan } \\
\text { kedepan }\end{array}$} & \multirow{2}{*}{$\begin{array}{l}\text { Indeks } \\
\text { Daya } \\
\text { Penye- } \\
\text { baran }\end{array}$} & \multirow{2}{*}{$\begin{array}{c}\text { Indeks } \\
\text { Derajat } \\
\text { Kepe- } \\
\text { kaan }\end{array}$} \\
\hline & & Nilai & $\begin{array}{l}\text { Ran- } \\
\text { king }\end{array}$ & Nilai & $\begin{array}{l}\text { Ran- } \\
\text { king }\end{array}$ & & \\
\hline 8 & Bangunan & 1,469 & 8 & 1,694 & 5 & 1,020 & 1,177 \\
\hline 9 & Perdagangan besar \& eceran & 1,476 & 6 & 2,878 & 1 & 1,025 & 1,999 \\
\hline 10 & Hotel & 1,682 & 3 & 1,019 & 12 & 1,168 & 0,708 \\
\hline 11 & Restoran & 1,496 & 5 & 1,014 & 14 & 1,039 & 0,704 \\
\hline 12 & Pengangkutan & 1,696 & 2 & 2,240 & 3 & 1,178 & 1,556 \\
\hline 13 & Komunikasi & 1,224 & 14 & 1,127 & 6 & 0,850 & 0,783 \\
\hline 14 & $\begin{array}{l}\text { Keuangan, persewaan dan jasa } \\
\text { perusahaan }\end{array}$ & 1,465 & 9 & 1,018 & 13 & 1,018 & 0,707 \\
\hline 15 & Jasa-jasa & 1,476 & 7 & 2,618 & 2 & 1,025 & 1,818 \\
\hline 16 & Hiburan \& rekreasi & 1,505 & 4 & 1,079 & 9 & 1,046 & 0,749 \\
\hline
\end{tabular}

Daya penyebaran dinotasikan dengan ${ }^{\alpha j}$ dan derajat kepekaan dinotasikan dengan $\beta j$, merupakan perbandingan dampak baik kebelakang atau kedepan terhadap rata-rata seluruh dampak sektor lapangan usaha, sehingga disebut juga sebagai backward linkage effect ratio dan forward linkage effect ratio. Nilai ${ }^{\alpha j}>1$ dan ${ }^{\beta j}>1$ merupakan sektor yang strategis dalam memacu pertumbuhan ekonomi.

\section{Analisis Dampak Pengganda (Multiplier Effect)}

Semua sektor yang terkait dengan kepariwisataan mempunyai angka pengganda output yang tinggi. Tingkatan angka penggandanya di dalam 16 sektor lapangan usaha yang ada yaitu sektor pengangkutan (ranking 2), sektor hotel (ranking 3), sektor hiburan \& rekreasi (ranking 4), sektor restoran (ranking 5), dan sektor perdagangan besar \& eceran (ranking 6). Apabila di lihat lebih cermat nilai pengganda output adalah merupakan nilai keterkaitan kebelakang dari suatu perekonomian. Nilai sebesar 1,476 pada sektor perdagangan besar \& eceran menunjukan bahwa apabila terjadi tambahan permintaan akhir sebesar satu unit rupiah pada sektor tersebut maka output yang tercipta dalam perekonomian adalah sebesar 1,476, begitu pula interpretasinya untuk sektor lain.

Meningkatnya permintaan akhir pada suatu sektor akan memberikan dampak terhadap penambahan output atau produksi suatu barang dan jasa, secara otomatis akan membutuhkan tambahan tenaga kerja untuk memproduksi barang dan jasa tersebut sebagai input primernya. Akibat penambahan tenaga kerja akan meningkatkan upah dan gaji yang diterima sebagai balas jasa yang diberikan dalam proses produksi. Peningkatan upah dan gaji inilah yang dinamakan tambahan pendapatan rumah tangga. Pengaruh sektor yang berhubungan dengan kepariwisataan terhadap pendapatan rumah tangga dengan angka pengganda pendapatan rumah tangga yang relatif tinggi yaitu sektor pengangkutan (ranking 2) dan sektor hiburan \& rekreasi (ranking 3). Sedangkan sektor lainnya hanya mempunyai angka pengganda sedang yaitu sektor hotel (ranking 6), sektor restoran (ranking (7) dan sektor perdagangan besar \& eceran (ranking (9) dari 16 sektor dalam perekonomian.

Tabel 2. Angka Pengganda Sektor Perekonomian

\begin{tabular}{c|c|c|c|c|c|c|c}
\hline \multirow{2}{*}{ No } & \multirow{2}{*}{ Sektor } & \multicolumn{6}{c}{ Angka Pengganda } \\
\cline { 3 - 8 } & & \multicolumn{2}{|c|}{ Output } & \multicolumn{2}{c}{ Pendapatan } & \multicolumn{2}{c}{ Tenaga Kerja } \\
\cline { 3 - 8 } & & Nilai & $\begin{array}{c}\text { Ran- } \\
\text { king }\end{array}$ & Nilai & $\begin{array}{c}\text { Ran- } \\
\text { king }\end{array}$ & Nilai & $\begin{array}{c}\text { Ran- } \\
\text { king }\end{array}$ \\
\hline 1 & Tanaman bahan makanan & 1,111 & 15 & 0,188 & 16 & 0,008 & 13 \\
\hline
\end{tabular}




\begin{tabular}{|c|c|c|c|c|c|c|c|}
\hline \multirow{3}{*}{ No } & \multirow{3}{*}{ Sektor } & \multicolumn{6}{|c|}{ Angka Pengganda } \\
\hline & & \multicolumn{2}{|c|}{ Output } & \multicolumn{2}{|c|}{ Pendapatan } & \multicolumn{2}{|c|}{ Tenaga Kerja } \\
\hline & & Nilai & $\begin{array}{l}\text { Ran- } \\
\text { king }\end{array}$ & Nilai & $\begin{array}{l}\text { Ran- } \\
\text { king }\end{array}$ & Nilai & $\begin{array}{l}\text { Ran- } \\
\text { king }\end{array}$ \\
\hline 2 & Tanaman perkebunan & 1,406 & 10 & 0,294 & 12 & 0,012 & 10 \\
\hline 3 & Peternakan dan hasilnya & 1,283 & 13 & 0,385 & 4 & 0,010 & 12 \\
\hline 4 & Perikanan & 1,088 & 16 & 0,190 & 15 & 0,007 & 14 \\
\hline 5 & Pertambangan dan penggalian & 1,372 & 12 & 0,282 & 13 & 0,006 & 16 \\
\hline 6 & Industri pengolahan & 1,382 & 11 & 0,365 & 8 & 0,031 & 2 \\
\hline 7 & Listrik, gas dan air bersih & 1,907 & 1 & 0,326 & 11 & 0,017 & 7 \\
\hline 8 & Bangunan & 1,469 & 8 & 0,374 & 5 & 0,020 & 3 \\
\hline 9 & Perdagangan besar \& eceran & 1,476 & 6 & $\mathbf{0 , 3 5 5}$ & 9 & $\mathbf{0 , 0 3 2}$ & 1 \\
\hline 10 & Hotel & 1,682 & 3 & $\mathbf{0 , 3 6 9}$ & 6 & 0,019 & 6 \\
\hline 11 & Restoran & 1,496 & 5 & $\mathbf{0 , 3 6 8}$ & 7 & $\mathbf{0 , 0 1 5}$ & 8 \\
\hline 12 & Pengangkutan & 1,696 & 2 & $\mathbf{0 , 4 6 3}$ & 2 & 0,013 & 9 \\
\hline 13 & Komunikasi & 1,224 & 14 & 0,251 & 14 & 0,007 & 15 \\
\hline 14 & $\begin{array}{l}\text { Keuangan, persewaan dan jasa } \\
\text { perusahaan }\end{array}$ & 1,465 & 9 & 0,330 & 10 & 0,010 & 11 \\
\hline 15 & Jasa-jasa & 1,476 & 7 & 0,693 & 1 & 0,019 & 4 \\
\hline 16 & Hiburan \& rekreasi & 1,505 & 4 & 0,422 & 3 & 0,019 & 5 \\
\hline
\end{tabular}

Dampak pengganda tenaga kerja sektor pariwisata yang relatif tinggi adalah sektor perdagangan besar \& eceran (ranking 1), dan hiburan \& rekreasi (ranking 5) dan hotel ranking (6). Sedangkan restoran dan pengangkutan hanya menduduki ranking 8 dan 9 dari 16 sektor yang ada dalam perekonomian Kota Bukittinggi, yang mencerminkan sektor ini adalah sektor yang padat modal.

\section{Analisis Penerapan Input Finansial Belanja Pemerintah dan Investasi}

Apabila belanja pemerintah di perkirakan naik 11\% dari Tahun 2012 menjadi Rp579.646.247.003,-, dan investasi sesuai peluang yang ada sebesar Rp58,396 M, yang kemudian dialokasikan kedalam beberapa simulasi (Tabel 3), akan dilihat pengaruhnya terhadap output, pendapatan dan tenaga kerja yang tercipta. Begitu pula dengan investasi.

Penerapan input finansial terhadap pengeluaran belanja pemerintah pada skenario I simulasi 1, 2 dan 3, pengaruh yang paling besar baik terhadap output, pendapatan dan tenaga kerja adalah pada simulasi 2, dimana pengeluaran belanja pemerintah di alokasikan lebih besar terhadap sektor pariwisata. Begitu pula penerapan input finansial pada komponen investasi skenario II baik simulasi 1, 2 dan 3, terlihat bahwa pengaruh yang paling besar untuk output dan pendapatan rumah tangga adalah simulasi 3 , dimana input finansial hanya dialokasikan kepada sektor kepariwisataan. Tetapi dalam penciptaan tenaga kerja baru penerapan simulasi 1 lebih memberikan pengaruh yang besar. Ini terjadi disebabkan input finansial dialokasikan kepada sektor yang memang mempunyai nilai koefisien tenaga kerja yang tinggi, seperti sektor bangunan, perdagangan besar \& eceran dan hiburan \& rekreasi.

Tabel 3. Alokasi Penerapan Input Finansial Belanja Pemerintah dan Investasi

\begin{tabular}{|c|c|c|}
\hline Alokasi & Belanja Pemerintah (Skenario I) & Investasi (Skenario II) \\
\hline Simulasi 1 & $\begin{array}{l}\text { Alokasi secara merata kesemua } \\
\text { sektor }\end{array}$ & $\begin{array}{l}\text { Alokasi sesuai peluang yang ada } \\
\text { (Sektor perdagangan } \pm 30 \quad \mathrm{M} \text {, } \\
\text { Kebersihan (bangunan) } \pm 11,396 \mathrm{M} \text {, } \\
\text { dan Hiburan \& rekreasi } \pm 17 \mathrm{M} .\end{array}$ \\
\hline
\end{tabular}




\begin{tabular}{c|l|l}
\hline Alokasi & \multicolumn{1}{|c|}{ Belanja Pemerintah (Skenario I) } & \multicolumn{1}{c}{ Investasi (Skenario II) } \\
\hline Simulasi 2 & $\begin{array}{l}50 \% \text { untuk sektor pariwisata \& 50\% } \\
\text { untuk sektor lain }\end{array}$ & Dibagi secara merata kesemua sektor \\
\hline Simulasi 3 & $\begin{array}{l}25 \% \text { untuk sektor pariwisata \& 75\% } \\
\text { untuk sektor lain }\end{array}$ & $\begin{array}{l}\text { Hanya dialokasikan kepada sektor } \\
\text { pariwisata dengan porsi yang sama }\end{array}$ \\
\hline
\end{tabular}

Tabel 4. Hasil Penerapan Input Finansial

\begin{tabular}{c|c|r|r|r}
\hline \multirow{2}{*}{ No } & \multirow{2}{*}{ Penerapan } & \multicolumn{3}{|c}{ Dampak Input Finansial } \\
\cline { 2 - 4 } & & \multicolumn{1}{c}{ Output } & \multicolumn{1}{c}{ Pendapatan } & Tenaga Kerja \\
\hline 1 & Skenario I & & & \\
\hline & Simulasi 1 & $834.552,53$ & $204.852,74$ & 8.849 \\
\hline & Simulasi 2 & $\mathbf{8 5 5 , 2 9 9 , 6 0}$ & $\mathbf{2 1 1 . 4 9 4 , 6 7}$ & $\mathbf{9 . 5 2 4}$ \\
\hline & Simulasi 3 & $827.636,84$ & $202, .638,77$ & 8.625 \\
\hline 2 & Skenario II & & & $\mathbf{1 . 5 0 7}$ \\
\hline & Simulasi 1 & $86.616,50$ & $22.095,51$ & 892 \\
\hline & Simulasi 2 & $84.076,33$ & $20.637,73$ & $\mathbf{1 . 1 4 1}$ \\
\hline & Simulasi 3 & $\mathbf{9 1 . 7 4 0 , 2 0}$ & $\mathbf{2 3 . 0 9 1 , 2 2}$ & \\
\hline 3 & Kombinasi Optimal & & & $\mathbf{1 1 . 0 3 1}$ \\
\hline & SK I SM 2 \& SK II SM 1 & $\mathbf{9 4 1 . 9 1 6 , 1 0}$ & $\mathbf{2 3 3 . 5 9 0 , 1 8}$ & $\mathbf{1 0 . 6 6 5}$ \\
\hline & SK I SM 2 \& SK II SM 3 & $\mathbf{9 4 7 . 0 3 9 , 8 0}$ & $\mathbf{2 3 4 . 5 8 5 , 8 9}$ & \\
\hline
\end{tabular}

Pengaruh optimal dari kombinasi penerapan skenario I dan II adalah, kombinasi antara Skenario I Simulasi 2 dan Skenario II Simulasi 1. Apabila kebijakan pemerintah daerah adalah untuk meningkatkan jumlah kesempatan kerja yang lebih besar. Penerapan kombinasi pertama ini akan menciptakan output dan pendapatan rumah tangga yang sedikit lebih kecil, akan tetapi jumlah tenaga kerja yang tercipta lebih banyak. Kebijakan ini lebih baik apabila pemerintah daerah ingin mengurangi pengangguran yang ada di Kota Bukittinggi. Kombinasi kedua yaitu apabila Pemerintah Daerah Kota Bukittinggi ingin memfokuskan kepada peningkatan output dan pendapatan rumah tangga, dimana input finansial pengeluaran belanja pemerintah dengan alokasi anggaran lebih besar dan investasi dialokasikan untuk sektor yang strategis yaitu sektor pariwisata.

\section{Analisis Pengaruh terhadap Pola dan Struktur Ruang}

Secara spasial keterkaitan antar sektor pariwisata menunjukan bahwa keberadaan dan sebaran objek wisata sejarah yang berlokasi di sekitar pusat kota telah menarik kegiatan sektor-sektor lain yang terkait dengan pariwisata untuk berlokasi mendekati objek wisata tersebut. Berdasarkan daerah terbangunnya bentuk Kota Bukittinggi mencerminkan pola konsentris. Perkembangan bentuk pola ruang kota ke arah timur,utara dan selatan di pengaruhi oleh sistim jaringan jalan skala regional yang membentang dari utara ke selatan dan dari pusat kota ke arah barat. 


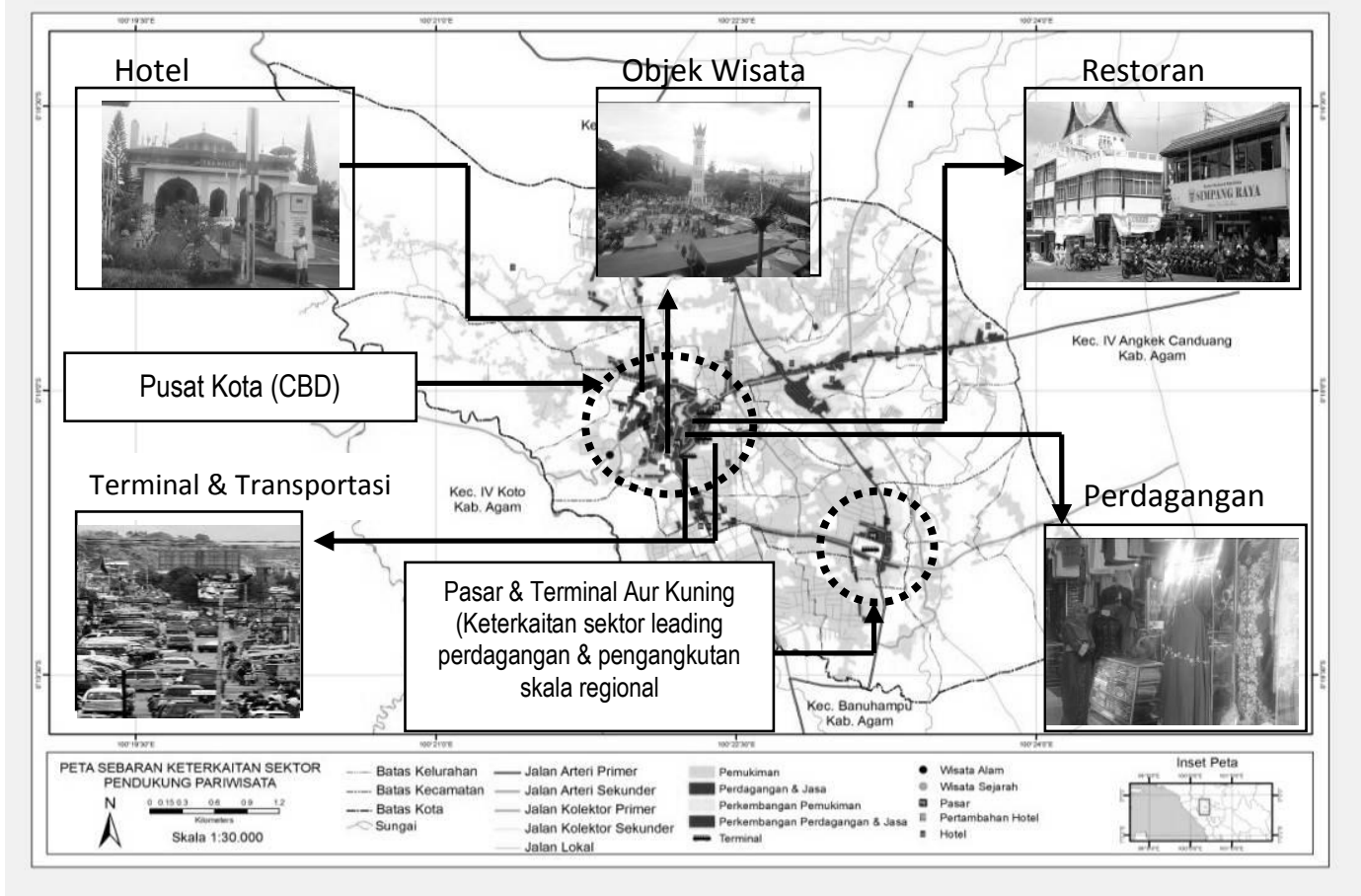

Sumber: RTRW Kota Bukittinggi 2010-2030, Google \& pengamatan, 2013

\section{Gambar 3. Keterkaitan Antarsektor Pariwisata Secara Spasial}

Struktur ruang kota di lihat dari kegiatan-kegiatan secara fungsional terdiri dari kegiatan pelayanan fungsi primer dan sekunder. Pusat pelayanan kota fungsi primer yang ada saat ini berada pada kawasan pasar atas (pusat kota/CBD) dengan fungsi pelayanan lebih di dominasi oleh kegiatan komersil dan pariwisata seperti, perdagangan (pasar atas, pasar bawah, pasar lereng dan pasar banto), perhotelan dan restoran. Disamping itu keberadaan 3 buah terminal di sekitar pusat kota serta aksesibilitas dari jaringan jalan yang semuanya mengarah ke pusat kota telah menjadikan kawasan pusat kota sebagai kawasan pusat pertumbuhan. Pusat pelayanan fungsi primer lainnya yaitu kawasan Pasar Aur Kuning, dengan kegiatan yang ada perdagangan \& jasa dan pergerakan regional, karena pada kawasan ini juga terdapat prasarana terminal tipe A yang mencerminkan keterkaitan yang kuat antara sektor perdagangan dan pengangkutan (Gambar 3). Pusat pelayanan fungsi sekunder terdapat pada kawasan Gulai Bancah dan Belakang Balok dengan kegiatan yaitu pemerintahan, pendidikan dan kesehatan.

Pola perkembangan permukiman kearah timur, utara dan selatan kota yang disebabkan meningkatnya permintaan akan perumahan dan bertambahnya jumlah penduduk lebih mengikuti keberadaan jaringan jalan. Pola perkembangan permukiman seperti ini di lihat dari bentuk fisik kota (morfologi), adalah pola perkembangan berbentuk gurita (octopus/start shaped cities). Dimana dalam perkembangannya jalur transportasi (jalan) sangat dominan mempengaruhi percepatan perkembangan kota ke wilayah pinggiran. Jalur transportasi ini tidak hanya satu arah saja, tetapi beberapa jalur yang mengarah keluar Kota Bukittinggi (Yunus: 2000).

Penggunaan ruang dilihat dari sebaran lokasi hotel di Kota Bukittinggi pada umumnya berada di sekitar pusat kota atau di sekitar objek wisata sejarah dan sebagian kecil menyebar di sepanjang jalan Sudirman dan jalan Soekarno Hatta. Penambahan jumlah hotel pada Tahun 2012 sebanyak 12 unit menjadi 70 unit bila dibandingkan dengan 
tahun 2008 hanya sebanyak 58 unit, juga lebih memilih lokasi berada di sekitar pusat kota dan dekat dengan sebaran objek wisata sejarah. Ini memperlihatkan bahwa keberadaan objek wisata sejarah telah mempengaruhi pemilihan lokasi untuk kegiatan perhotelan. Kegiatan kepariwisataan berupa perdagangan besar \& eceran, perhotelan, restoran, pengangkutan dan sebaran objek wisata telah membentuk struktur ruang kota yang terkonsentrasi pada suatu kawasan yaitu pusat kota dengan skala pelayanan lokal dan regional. Hanya saja pola perkembangan penggunaan lahan ke arah timur, utara dan selatan lebih banyak dipengaruhi oleh bertambahnya jumlah penduduk dan kegiatan perkotaan yang lain seperti perdagangan \& jasa, pendidikan, kesehatan dan perkantoran, dengan pola mengikuti jaringan jalan (ribbon)

\section{Kesimpulan}

Hasil penelitian mengungkapkan bahwa ditinjau dari struktur permintaan dalam perekonomian, peran sektor pariwisata (sektor perdagangan besar \& eceran, hotel, restoran, pengangkutan dan hiburan \& rekreasi) adalah sebesar 40,86\% apabila sektor lapangan usaha dikelompokan dalam sektor pertanian \& pertambangan, sektor industri, sektor pariwisata dan sektor jasa. Perbandingan antara permintaan antara dan permintaan akhir, lebih dari 55\% peran sektor pariwisata adalah untuk permintaan akhir. Keterkaitan sektor pariwisata dengan sektor lain dilihat dari indeks daya penyebaran dan derajat kepekaan, semua sektor yang terkait dengan kegiatan kepariwisataan mempunyai indeks daya penyebaran $>1$. Tetapi indeks derajat kepekaan $>1$ hanya terjadi pada sektor perdagangan besar \& eceran dan pengangkutan, sedangkan sektor hotel, restoran dan hiburan \& rekreasi mempunyai indeks $<1$. Begitu pula dampak pengganda (multiplier effect) semua sektor yang terkait kegiatan pariwisata mempunyai pengaruh yang relatif besar terhadap dampak pengganda baik output, pendapatan rumah tangga dan tenaga kerja. Penerapan skenario input finansial, memperlihatkan pengaruh sektor pariwisata terhadap perekonomian Kota Bukittinggi akan lebih besar apabila input finansial dialokasikan lebih besar terhadap sektor-sektor pariwisata, baik dalam bentuk pengeluaran belanja pemerintah maupun investasi. Keberadaan objek wisata di sekitar pusat kota telah mempengaruhi struktur kota, dimana kegiatan dan usaha yang terkait dengan pariwisata tertarik untuk berlokasi mendekati objek wisata. Namun pola perkembangan kota ke arah timur, utara dan selatan kota lebih dipengaruhi oleh keberadaan jaringan jalan.

\section{Daftar Pustaka}

Adisasmita, Rahardjo. 2005. Dasar-Dasar Ekonomi Wilayah. Yogyakarta : Penerbit Graha Ilmu

Arsyad, Lincolin, 1999. Pengantar Perencanaan dan Pembangunan Ekonomi Daerah. Yogyakarta : Penerbit BPFE

Bukittinggi Dalam Angka 2013. 2014. Badan Pusat Statistik Kota Bukittinggi

Daryanto, Arief dan Yundi, Hafisrianda. 2010. Model-Model Kuantitatif Untuk Perencanaan Pembangunan Ekonomi Daerah. Bogor : Penerbit IPB Press

Marpaung. Happy. 2002. Pengetahuan Kepariwisataan. Bandung : Penerbit Alfabeta

Nazara, Suahasil. 2005. Analisis Input Output. Jakarta: Lembaga Penerbit Fakultas Ekonomi Universitas Indonesia

Nazir, Mohamad. 2003. Metode Penelitian. Jakarta: Penerbit Ghalia Indonesia

Pendit, N.S. 1999. Ilmu Pariwisata Sebuah Pengantar Perdana. PT. Anem Kosong Anem 


\section{Pengaruh Sektor Pariwisata Terhadap Perekonomian dan Keruangan Kota Bukittinggi}

Penghitungan Dan Analisis Tabel Input Output Sumatera Barat 2007. 2009. Badan Pusat Statistik dan Bappeda Provinsi Sumatera Barat

Rencana Kerja Pembangunan Daerah Kota Bukittinggi Tahun 2012. 2011. Bappeda \& PM Kota Bukittinggi

Soekadijo. 1997. Anatomi Pariwisata (Memahami Pariwisata sebagai Systemic Linkage). Jakarta: Gramedia Pustaka Utama

Spillane, J J. 1994. Pariwisata Indonesia Siasat Ekonomi dan Rekayasa Kebudayaan. Yogyakarta: Penerbit Kanisius

Sugiyono. 2012. Metode Penelitian Kuantitatif, Kualitatif dan $R \& D$. Bandung : Penerbit Alfabeta

Tarigan, Robinson. 2004. Ekonomi Regional Teori dan Aplikasi. Jakarta : Penerbit PT. Bumi Aksara.

2005. Perencanaan Pembangunan Wilayah Edisi Revisi. Jakarta: Bumi Aksara

Wardiyanta. 2006. Metode Penelitian Pariwisata. Yogyakarta: Andi Offset

Yoeti, Oka A. 2008. Ekonomi Pariwisata Introduksi, Informasi dan Aplikasi. Jakarta: Kompas Media Nusantara

Yunus, Hadi. 2000. Struktur Tata Ruang Kota. Yogyakarta: Pustaka Pelajar 